DOI: $10.17516 / 1997-1370-0721$

УДК 796.07:378.147:004

\title{
Factor Structure of Physical Fitness of Students Engage in Golf (Based on Long-Term Monitoring)
}

\author{
Aleksey N. Korol'kov, Vyacheslav B. Anisimov, \\ Aleksey V.Andreev and Aleksey V. Bereza* \\ Siberian Federal University \\ Krasnoyarsk, Russian Federation
}

Received 07.02.2020, received in revised form 26.10.2020, accepted 05.02.2021

\begin{abstract}
The structure of the physical fitness of students engaged in golf has been studied on the basis of long-term observations. Methods of variance, correlation, and factor analysis were used to process the results of physical fitness tests of 242 male students. The structure and typical features of the physical development of students in the course of golf classes were formulated.
\end{abstract}

Keywords: motion abilities, game, sport.

Research area: theory and methodology of physical education, sports training, healthimproving and adaptive physical culture: management in the physical culture system.

Citation: Korol'kov, A.N., Anisimov, V.B., Andreev, A.V., Bereza, A.V. (2021). Factor structure of physical fitness of students engage in golf (based on long-term monitoring). J. Sib. Fed. Univ. Humanit. Soc. Sci., 14(2), 282-287. DOI: 10.17516/1997-1370-0721.

(c) Siberian Federal University. All rights reserved

* Corresponding author E-mail address: juniorgolf2012@mail.ru ORCID: 0000-0002-7921-1585 (Anisimov) 


\title{
Структура физической подготовленности юношей-студентов, занимающихся гольфом (по результатам многолетнего мониторинга)
}

\author{
А.Н. Корольков, В.Б.Анисимов, \\ A.В.Андреев, А.В. Бере̊за \\ Сибирский федеральный университет \\ Российская Федераиия, Красноярск
}

\begin{abstract}
Аннотация. На основе данных многолетних наблюдений физической подготовленности студентов, занимающихся гольфом, исследована ее структура. Для обработки результатов тестов физической подготовленности 242 юношей применяли методы дисперсионного, корреляционного и факторного анализа. Установлены структура и характерные особенности развития физических качеств студентов в процессе занятий гольфом.
\end{abstract}

Ключевые слова: двигательные способности, игра, спорт.

Научная специальность: 13.00.04 - теория и методика физического воспитания, спортивной тренировки, оздоровительной и адаптивной физической культуры.

\section{Introduction}

Golf is a kind of sport with the primary domination of coordination abilities, where physical fitness is manifested indirectly and does not seem to make a clear effect on the result of the game (Djerebko, Korolkov, 2013). As noted in (Djerebko, Korolkov, 2013; Korol'kov, 2012), the efficiency of every action in golf depends directly on the development degree of such coordination abilities as spatial ability, balance, sense of rhythm, repetition of movements, regulation, assessment and application of the direct strength or magnitude of swing, evaluation and measurement of the spatial, temporal and power parameters of movements, coordination of movements.

At the same time, on one hand, in the process of golf training some special physical qualities develop along with coordination abilities to a certain extent, and, on the other hand, the focused development on the physical qualities of the athlete contributes to the conjugate development of specific coordination abilities and the high achievements in golf (Korol'kov, 2012, Korol'kov et al., 2019). Golf training also makes a certain impact on the morphofunctional state of athletes (Baimukhametova, 2019; Burlakov, 2014).
By student age, the motion abilities and dynamic stereotypes have been developed to a high extent. The sensitive period for the development of dexterity, flexibility and speed is over. This late adolescence age is a sensitive period for the development of endurance and strength. At the same time, however, there is very little information about any research dedicated to the development of the psychomotor qualities required for golf at the given age.

\section{Problem}

In this regard, it appears relevant to study the structure of the physical fitness of students engaged in golf.

\section{Research methods and organization}

To solve this problem, the results of physical fitness tests of the Siberian Federal University students engaged in golf were processed. The research covered $1^{\text {st }}, 2^{\text {nd }}$, and $3^{\text {rd }}$-year students. Training sessions were held twice a week. The first 10-15 minutes of the session were allotted to the general warm-up, the main part of the session was dedicated to special physical exercises for swing training, and the final part was general physical preparation and practice with 
gold equipment. The physical tests involved in the research are standing long jump, pull-ups, abdominal twist curls for 20 seconds, side-throw of a $3 \mathrm{~kg}$ stuffed ball with both hands from the golf stance and standing forward fold.

The tests were carried out every semester of the academic years 2015-2019. The test involved 242 male students aged 18-21. In total, six data sets (for every semester) of 1210 digital values were processed.

The collected data were processed with a standard statistical procedure using the Stadia $8.0 /$ prof. software pack. The level of statistical significance of the hypotheses was equal to 0.05 .

\section{Results and discussions}

Using the Omega-square criterion, the type of distribution of the physical fitness test results was determined. It was found that in most cases (27 out of 30) the hypothesis that the distribution does not differ from the standard is true. For this reason, at the next stage, the parametric statistical methods of the source data analysis were used.

In each test, formula (1) was applied to determine the sufficient sample number N (Table 1) for attributing the sample variations of the initial data to the random cause effect, not to the small amount of data presented.

$$
N=(t S / \Delta)^{2} \text {, }
$$

where

$t$ is the critical value of the standardized normal distribution for the 1- $\beta$ statistical power;

$\mathrm{S}$ is the root mean square error of the selected measurements;

$\Delta$ is an acceptable sample error.

The $\beta$ value was admitted as equal to 0.8 $(t=1.36) . \Delta$ for the locomotion was admitted as follows for the given motion acts: $5 \mathrm{~cm}$ for standing jump, 0.5 meters for throwing, $1 \mathrm{~cm}$ for the forward fold; these are comparable with the pedagogically important values for these tests (Korol'kov, 2019).
Table 1 demonstrates that the studied data sample collected from 50-60 subjects was in most cases sufficient for further correct statistical comparisons.

To validate the hypothesis that there is a time factor effect on the response, the one-factor analysis of variance of stuffed ball throw and abdominal curls' test results was carried out. It may be therefore argued that regular golf training affects the muscles that cater to the torso rotation, an important element of the golfing technique (Korol'kov, 2012). Besides, for all time intervals, the Student's t-criterion was used to establish the statistically significant differences between the sample averages of these tests. The dynamics of the test results over time is illustrated in Fig. 1 and 2 .

The correlation analysis revealed statistically significant correlation coefficients (Z-criterion) between the test results: long jump - pull-ups - abdominal curls; pull-ups abdominal curls - stuffed ball throw; abdominal curls - stuffed ball throw. Moreover, the values of the correlation coefficients between the tests increased from the first to the sixth semester, indicating a complex conjugate development of speed-strength physical qualities in the golf training process.

The results of tests carried out among the students in the $1^{\text {st }}$ and $5^{\text {th }}$ semesters were processed with the canonical factor analysis method with the calculation of Pearson correlations, Kaiser normalization, and varimax rotation. The factor load and the share in the total dispersion of orthogonal factors were compiled by projections of variables. The test results collected in the $1^{\text {st }}$ and $5^{\text {th }}$ semesters are presented in Tables 2 and 3.

The data presented in Tables 2 and 3 manifest a significant change in the students' physical fitness structure in the golf training process. If at the beginning of training, in the first semester, three factors of preparedness are determined ( $86 \%$ of the general dispersion):

Table 1. Volumes of representative samples for statistical analysis (number of subjects)

\begin{tabular}{|c|c|c|c|c|}
\hline Standing jump & Pull-ups & Abdominal curls & Stuffed ball throw & Forward fold \\
\hline $20 \pm 6$ & $52 \pm 19$ & $28 \pm 11$ & $34 \pm 14$ & $61 \pm 9$ \\
\hline
\end{tabular}




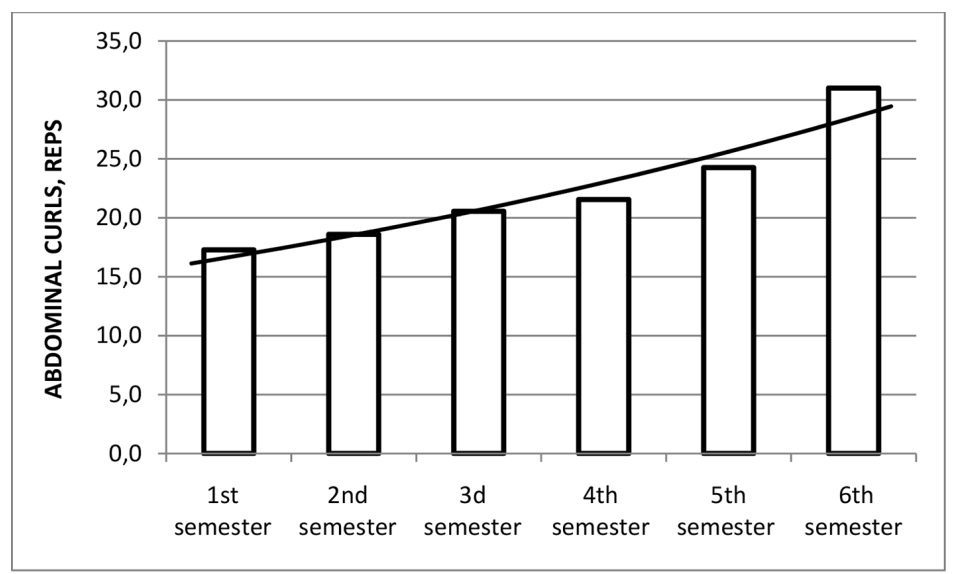

Fig. 1. Progress in test results: abdominal curls for 20 seconds in a prone position

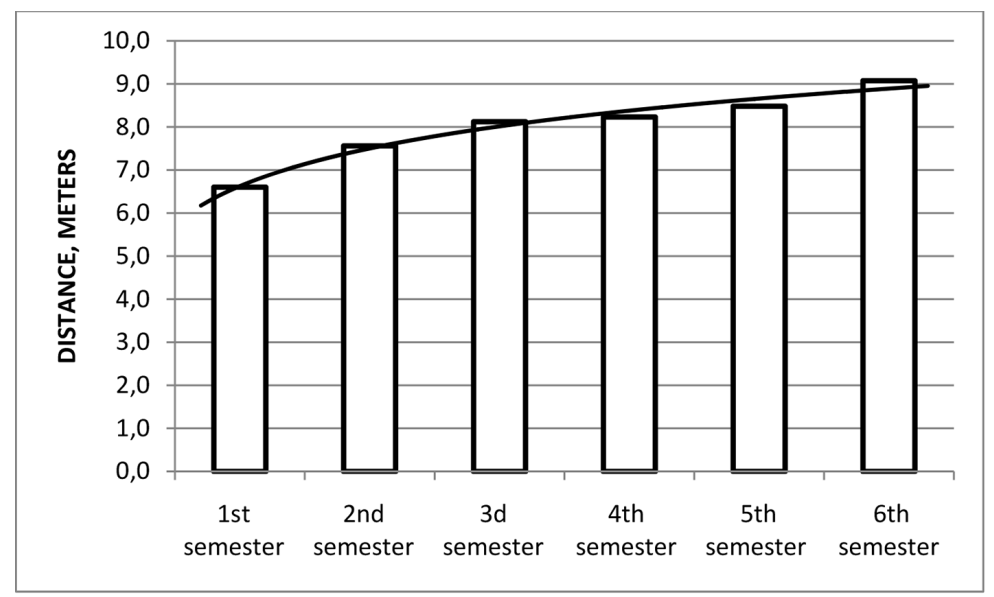

Fig. 2. Progress in test results: $3 \mathrm{~kg}$ stuffed ball throw

Table 2. Factor load and percentage of explained variance of students' physical fitness (1 ${ }^{\text {st }}$ semester)

\begin{tabular}{|c|c|c|c|}
\hline Variables $\backslash$ factors & 1 & 2 & 3 \\
\hline Long jump & 0.59 & -0.70 & \\
\hline Pull-ups & 0.78 & & \\
\hline Abdominal curls & 0.80 & & \\
\hline Stuffed ball throw & 0.68 & & 0.56 \\
\hline Forward fold & 0.70 & & 0.66 \\
\hline Eigenvalue & 2.52 & 0.88 & 13.14 \\
\hline Dispersion, $\%$ & 50.51 & 17.51 & 81.16 \\
\hline Cumulative disp. $\%$ & 50.51 & 68.02 & \\
\hline
\end{tabular}


Aleksey N. Korol'kov, Vyacheslav B. Anisimov... Factor Structure of Physical Fitness of Students Engage in Golf...

Table 3. Factor loads and percentage of explained variance of students' physical fitness ( $5^{\text {th }}$ semester)

\begin{tabular}{|c|c|c|c|c|}
\hline Variables/factors & 1 & 2 & 3 & 4 \\
\hline Long jump & 0.67 & & -0.63 & \\
\hline Pull-ups & 0.73 & & & \\
\hline Abdominal curls & & -0.75 & & 0.59 \\
\hline Stuffed ball throw & 0.68 & & & 0.77 \\
\hline Forward fold & & 0.64 & 0.81 & 15.34 \\
\hline Eigenvalue & 1.84 & 1.05 & 16.22 & 89.35 \\
\hline Dispersion, $\%$ & 36.78 & 21.01 & 74.01 & \\
\hline Cumulative disp., $\%$ & 36.78 & 57.79 & & \\
\hline
\end{tabular}

- general physical fitness factor (51\%), compiled by the values of all variables (tests);

- leg muscles functional factor (18\%) (standing long jump);

- flexibility factor (13\%).

After 2.5 years of golf training, in the fifth semester, the physical fitness structure becomes more specific. It consists of the four preparedness factors that underlie $89 \%$ of the variation in the test results.

The first factor $(37 \%$ of the total dispersion) is speed-strength training factor manifested in the explosive strength (long jump and ball throw) and power endurance (pullups).

The second factor (21\%) is interpreted as a torso flexing muscle group development;

The third factor $(16 \%)$ is the factor of speed-strength abilities that ensure the coordination of limb movements.

And finally, the fourth factor $(15 \%)$ is the flexibility factor determined by the forward fold test.

\section{Conclusions}

The structure of the physical fitness of students engaged in golf was studied to discover that regular golf exercises affect the corresponding muscle groups that ensure rotation of the torso which is an important element of the game technique. As a result, statistically significant correlations between the physical fitness tests were determined as follows: long jump - pull-ups - abdominal curls; pull-ups abdominal curls - stuffed ball throw; abdominal curls - stuffed ball throw. Moreover, the values of the correlation coefficients between these tests increased from the first to the sixth semester, manifesting a complex conjugate development of speed-strength physical qualities in the golf training process.

The factor analysis method revealed that the structure of the physical fitness in students changes significantly in the gold training process. After 2.5 years of training, the physical fitness structure became more focused, determined by the factors of speed and strength abilities and the flexibility factor.

\section{References}

Baimukhametova, E.F., Nenesheva, A.V., Aminov, A.S. (2019). Bioimpedansnyy analiz sostava tela sportsmenov-gol'fistov na protyazhenii godovogo trenirovochnogo protsessa [Bioimpedance analysis of the body composition of golfers during the annual training process]. In Teoriya i praktika fizicheskoy kul'tury [Theory and practice of physical education], 1, 26-28.

Burlakov, I.U., Verchenova, A.V., Korol'kov, A.N. (2014). Rezul'taty antropologicheskogo monitoringa igrokov v gol'f vysokoy kvalifikatsii [Highly qualified golf players' anthropological monitoring results]. In Vestnik Chelyabinskogo gosudarstvennogo universiteta. Obrazovaniye i zdravookhraneniye [Bulletin of Chelabinsk State University. Educational and health], 1, 57-62. 
Djerebko D.S., Korolkov, A.N. (2013). Ekspertnaya otsenka napravlennosti sportivnoy podgotovki federal'nogo standarta po gol'fu [Expert assessment of the focus of sports training of the federal golf standard]. In Fizicheskaya kul'tura: vospitaniye, obrazovaniye, trenirovka [Physical education: upbringing, education, training], 6, 68.

Korol'kov A.N. (2012). Tsentroidnyy metod glavnykh komponentov dlya otsenki obshchey fizicheskoy podgotovlennosti igrokov $\mathrm{v}$ gol'f [The centroid method of the main components for assessing the overall physical fitness of golfers]. In Fizicheskaya kul'tura: vospitaniye, obrazovaniye, trenirovka [Physical education: upbringing, education, training], 4, 30-33.

Korol'kov, A.N., Chebin, V.G., Anisimov, V.B., Bereza, A.V. (2019). Osobennosti vliyaniya zanyatiy gol'fom na fizicheskuyu podgotovlennost' studentok [Features of the impact of golf on the physical fitness of students]. In Teoriya i praktika fizicheskoy kul'tury [Theory and practice of physical education], 6, 63-65. 